\title{
Cross-Border E-Commerce - Myth or Reality. Review of Major Harmonisation Efforts
}

\begin{abstract}
Bartosz Targański*, Anna Mokrysz-Olszyńska**
The goal of the article is to review selected initiatives on harmonising the legal framework for international e-commerce. The article focuses on the achievements of two institutions with the greatest achievements in the field of harmonisation of the rules of international trade, i.e. the United Nations Commission on International Trade Law (UNCITRAL) (global dimension) and the European Commission (regional level of the European Union). Taking up this issue is justified by the fact that in spite of the dynamic increase in the absolute number of e-commerce transactions, a vast majority of them are domestic transactions within particular countries. In order to better use the potential of the Internet in international trade, it is necessary to further harmonise regulations on online transactions at the international level. The article points to significant achievements in terms of harmonisation of regulations on e-commerce within the EU, and the simultaneous lack of significant progress in terms of harmonisation in a broader global perspective.
\end{abstract}

Keywords: e-commerce, legal harmonisation, internal market, European Union, UNCITRAL.

Submitted: 14.12.2016 | Accepted: 01.03.2017

\section{Transgraniczny handel elektroniczny - mit czy rzeczywistość. Przegląd głównych działań harmonizacyjnych}

Celem artykutu jest przeglad wybranych inicjatyw harmonizujacych ramy prawne międzynarodowego handlu elektronicznego. Artykut koncentruje się na dokonaniach dwóch instytucji o największym dorobku w zakresie harmonizacji uregulowań handlu międzynarodowego, tj. Komisji Narodów Zjednoczonych ds. Międzynarodowego Prawa Handlowego (wymiar globalny) i Komisji Europejskiej (wymiar regionalny Unii Europejskiej). Podjęcie tego zadania uzasadnione jest faktem, że dynamiczny wzrost znaczenia handlu elektronicznego w niewielkim stopniu dotyczy transakcji transgranicznych. Z kolei większe wykorzystanie potencjału Internetu w handlu międzynarodowym wymaga szerokiej harmonizacji uregulowań prawnych w ujęciu międzynarodowym. Artykut wskazuje na znaczace osiagnięcia, jeśli chodzi o har-

* Bartosz Targański, PhD - Legal counsel, assistant professor at Warsaw School of Economics (SGH), Marketing Strategy Unit, Institute of International Management and Marketing, Collegium of World Economy.

** Anna Mokrysz-Olszyńska, SGH - Professor (associate professor) at Warsaw School of Economics (SGH), Marketing Strategy Unit, Institute of International Management and Marketing, Collegium of World Economy, Warsaw School of Economics.

Mailing address: Warsaw School of Economics (SGH), Institute of International Management and Marketing; ul. Madalińskiego 6/8 M, pok.nr 10,02-513 Warsaw; e-mail: btarga@sgh.waw.pl; amokry@ sgh.waw.pl. 
monizację uregulowań handlu elektronicznego w ramach ugrupowania integracyjnego, jakim jest UE i jednoczesny brak istotnego postępu, jeśli chodzi o harmonizację w szerszej globalnej perspektywie. Ze względu na istnienie różnic w systemach prawnych, potencjat Internetu, jako forum handlu międzynarodowego, nie jest w petni wykorzystany.

Słowa kluczowe: handel elektroniczny, harmonizacja prawa, rynek wewnętrzny, Unia Europejska, UNCITRAL.

Nadesłany: 14.12.2016 | Zaakceptowany do druku: 01.03.2017

JEL: K330, F530, M380

\section{Introduction}

Since its dawn, tied to the development of trade in cities of the Mediterranean Sea basin, then in cities of medieval Europe, commercial law has always had an international character. It loses that nature in the period of absolutism (16 ${ }^{\text {th }}-18^{\text {th }}$ centuries), as states start extending legal restrictions imposed on trade. At least that is what happens in continental Europe; because in the meantime, since the $11^{\text {th }}$ century, England has been developing a separate system of case law - the so-called common law.

The co-existence of various domestic legal orders, sometimes varying substantially from each other not only in terms of solutions to detailed issues but also in their approach to legal issues, together with the concurrent progress of international trade, creates two problems. On the one hand, it prompts the need to establish rules determining which legal system is applicable to a situation or legal relation with a foreign element (conflict-of-law rules, or in a wider sense - international private law); on the other hand, in the face of the growing complexity of legal matters ${ }^{1}$, it calls for harmonisation of commercial law.

However, it is only the 19th century that brings a dynamic development of international commerce and thus gives rise to the process of establishing international commercial law. The traditional method of establishing the international commercial law consists in drafting international agreements (conventions). Besides the traditional method, the soft method has garnered a lot of support over the past decades, which involves the creation of template regulations, model laws, legal manuals, guidelines of international organisations (like the OECD), etc., where these tem- plates are to be used by the state when creating external law or by the parties to the agreement, by way of including these in the content of the agreements concluded ${ }^{2}$. What is more, specific unifying solutions have been devised in the EU under the integration method, which creates the EU law or harmonises the legislation in the member states.

Inasmuch as the traditional method involves the laborious path of drafting conventions, which hardly ever become common $^{3}$, and the soft method, though easier to implement and thus more readily applied, has limited effectiveness, one may safely consider the method of creating standardised law within the EU as one of the most effective. And yet, its chief shortcoming is that the scope of this method is limited to the EU member states.

From the e-commerce perspective, it would be best to globally harmonise the entirety of commercial rules. However, the road to such far-reaching standardisation is still long, even though there are certain achievements in respect of the unification process, with regard to both $\mathrm{B} 2 \mathrm{~B}$ trade as well as B2C trade.

Both classic rules of private international law, settling conflicts of laws, as well as the strive towards unification of material commercial law on a global scale, refer to international trade in the sense of classic cross-border transactions ${ }^{4}$. However, technological changes brought on by the $21^{\text {st }}$ century have shaped a new perspective: the perspective of truly cross-border commercial traffic. Online transactions are characterised by detachment from space; classic linking factors, connecting a certain situation or legal relationship with a concrete legal system, are increasingly ill-adapted to virtual reality. What arises are questions 
on the applicability of classic norms of international private law, as well as of the standardisation achievements to date with regard to commercial contract law and in relation to the needs of cross-border transactions concluded online; one may ask to what extent the current legal framework eases the use of the Internet in international trade - and to what extent it hampers that use, by erecting barriers.

In this respect, one ought to pay attention to the solutions adopted in the United Nations Convention on Contracts for the International Sale of Goods, as well as in the EU law. One should in particular consider the consequences, for cross-border e- commerce in general for traders and for consumers alike, brought on by the Directive 2011/83/EU of the European Parliament and of the Council of 25 October 2011 on consumer rights (Consumer Rights Directive or CRD). What will be of chief significance in the future are legislative measures taken in relation to the European Union, aimed at carrying out the Digital Single Market strategy adopted on 6 May 2015 by the European Commission.

\section{Contracts for the International Sale of Goods}

Since 1 June 1996, Poland has been bound by the United Nations Convention on Contracts for the International Sale of Goods, drafted in Vienna on 11 April 1980 (Vienna Convention). Consequently, at the moment the Vienna Convention is the applicable law for a majority of international sale contracts of the professional (B2B) kind. The significance of the Vienna Convention for international trade stems, first of all, from its universal validity: it has been already ratified by 85 states (status as of 3.5.2016), which represent about $75 \%$ of the world trade, including all continental European countries; secondly, it stems from the opt out solution adopted in the Vienna Convention: provisions contained therein directly bind the parties to a sales contract, unless they agreed to the contrary (i.e. the parties to a contract may, in line with relatively binding provisions, freely determine detailed solutions to various issues in the contract, without having to adhere to solutions adopted in the Vienna Convention; moreover, they may exclude provisions of the Vienna Convention in part or as a whole; however, if they fail to do so, the Vienna Convention will be applicable). This concerns both situations when the parties to a contract for the sale of goods have their place of business in contracting states, as well as situations when the law applicable to a contract is the law of a contracting state (based on conflict-of-laws regulations, including the case when the parties to a contract select the applicable law $)^{5}$.

The binding force of the Vienna Convention means that different legal regimes apply to contracts of sale within the confines of domestic B2B trade and to international B2B contracts (irrespective of disparate regulations applying to consumer sale contracts, which will be discussed later on).

In spite of the doubtless success of the Vienna Convention in standardising the base contract in international trade, i.e. the contract for the sale of goods, and despite its being up to date with the development of means for long-distance communication as of that time ${ }^{6}$, the technological leap that has occurred since its adoption in 1980 has triggered the need for updating solutions, so that it reflects the e-commerce reality.

\section{Using Electronic Communications in International Contracts}

\subsection{Scope of the Regulation}

UNCITRAL took up the challenge of adjusting conventions regulating international trade to date, in particular the Vienna Convention, to the reality of electronic commerce, by drafting the United Nations Convention on the Use of Electronic Communications in International Contracts of 23 November 2005 (ECC). The purpose the $\mathrm{EEC}$ is to remove obstacles to the use of electronic communications in international contracts. In order to increase the certainty of electronic communication in contractual relations between businesses from different countries, it is of great importance that basic terms referring to such communication, as well as the way of determining the place of business of a party to the contract, the mode of dispatching and confirming actions and the application of automatic ICT systems are specified in detail. To this aim, the EEC:

- ensures that online contracts are equally valid and enforceable as contracts entered into traditionally (Art. 8.1); 
- introduces the equivalence of the written and of the electronic form and determines the criteria of authentication methods (Art. 9);

- defines the terms vital for the conclusion of contracts in the online environment such as "communication", "electronic communication", "originator", "addressee" and "place of business" (Art. 4).

Further details on the place of business are provided in Art. 6, according to which "the place of business location is not a place of business merely because that is (a) where equipment and technology supporting an information system used by a party in connection with the formation of a contract are located; or (b) where the information system may be accessed by the parties" (Art. 6.4), and "The sole fact that a party makes use of a domain name or electronic mail address connected to a specific country does not create a presumption that its place of business is located in that country" (Art. 6.5). This indicates that if, at a specific location, there is for instance a website server or a system that may be available for others, it does not determine the possibility of acknowledging the said location as the place of business; also using domains or e-mail addresses tied to a particular country does not provide presumption that the place of business is in that country.

What is important for the business practice is also the clarification of the moment of dispatch and the moment of receipt of electronic communication (Art. 10). Moreover, a proposal to conclude an online contract which is not addressed to one or more specific parties is to be considered as an invitation to make offers, unless it clearly indicates the intention of the party making the proposal to be bound in case of acceptance (Art. 11).

\subsection{Status of Ratification}

The substantive rules of the ECC strive to regulate the basic terms and standards and thus constitute an important legislative model for regulating international online trade. One can only regret that in spite of 11 years having passed since the adoption of the ECC, it has not become common law following the example of the Vienna Convention. So far only seven countries have ratified it (20 have signed it), and there are no EU member states among them ${ }^{7}$.
As stated in the opinion of the Polish ICT Chamber (Polska Izby Informatyki i Telekomunikacji, PIIT) on Poland signing and ratifying the UNCITRAL Convention on the Use of Electronic Communications in International Contracts (2006): "From the point of view of the Polish legislator the Convention fills a gap concerning the use of electronic communications in international trade with non-EU states. The effectiveness and the real role of the Convention depends on the number of States that decide to accede it. One ought to note that China and Singapore, among others, are signatories to the act. One may expect more states to accede the Convention in the near future. It is the stance yet to be presented by developed countries that will play a significant role in that matter" (Polska Izba Informatyki i Telekomunikacji, 2006) $)^{8}$.

Indeed, the significance of the EEC depends on the stand of leading countries, including EU member states. It would be simplest if the whole EU were to directly accede as party to the ECC - as the Convention itself provides for such a possibility (Art. 17). Nevertheless, from the point of view of business practice one should avoid a situation which the PIIT cautions about in case of Poland joining the ECC, namely "when different legal regimes exist concurrently, depending on whether the two parties to a contract have their place of business in Poland, or whether one of the traders has its place of business in Poland and the other in an EU member state; or, finally, whether contacts involve a Polandbased trader and another one established in a Convention member state" (Polska Izba Informatyki i Telekomunikacji, 2006; Waglowski, 2006).

One of the undeniable advantages of the ECC is that it is deeply set in other acts of international trade law created under the auspices of UNCITRAL, the Vienna Convention and the model law on electronic commerce and on electronic signatures in particular. This underlies the potential of the ECC becoming an impulse for the creation of a standardised law regulating international e-commerce. Cooperation in this respect seems indispensable since, restricted to the single market of the EU, the harmonisation of the legal framework for electronic commerce is insufficient in view of the nature of the Internet ${ }^{9}$. 


\section{Consumer Protection in Online Contracts}

\subsection{Need for Consumer Protection}

E-commerce creates enormous opportunities for consumers and businesses, including small and medium companies. By using the Internet, consumers can take advantage of price differences between countries. At the same time, SMEs may offer their products to a potentially unlimited number of buyers without the need to build up and maintain expensive distribution networks. In order to fully utilise this potential, consumers' rights need to be adequately protected in the online environment. At the same time, the scope of protection offered online to consumers should not differ significantly between countries, as those differences may be considered as barriers for companies interested in cross-border sales. Such assumptions guided the creation of the Consumer Rights Directive.

\subsection{Scope of Harmonisation}

The Consumer Rights Directive charts a new direction for the development of consumer law within the EU because it replaced the minimum harmonisation approach with maximum harmonisation (Mokrysz-Olszyńska, 2013). The CRD introduced significant changes in relation to off-premises contracts and distance contracts, including those concluded on the Internet. Apart from standardising terms, including the definition of a "consumer", "off-premises contract" and "distance contract" as well as the definitions of such notions as "durable medium", "digital content", the CRD changed the range of information the trader is obliged to provide to the consumer and the right to withdraw from a contract in off-premises contracts and distance contracts. Detailed information requirements in this respect are mentioned in Art. 6, which lists 21 points the consumer should be informed about by the trader in a clear and comprehensible way before concluding a contract. If the trader has not complied with the information requirements on additional charges or other costs or on the costs of returning the goods, the consumer should not bear those charges or costs (Art. 6.6).

Among the formal requirements concerning online contracts, one ought to pay attention to Art. 8.2, i.e. directly before placing an order, the consumer should be made aware in a clear and prominent manner about the key features of the product or services. The trader should also ensure that the consumer, when placing his order, explicitly acknowledges that the order implies an obligation to pay. If placing an order entails activating a button or a similar function, the button or similar function shall be labelled in an easily legible manner only with the words 'order with obligation to pay' or a corresponding unambiguous formulation indicating that placing the order entails an obligation to pay. If the trader has not complied with this obligation, the consumer should not be bound by the contract or order.

Also the subsequent paragraph of Art. 8 of the CRD refers directly to e-commerce and contains a requirement for websites to feature clear and legible information on potential limitations concerning the delivery and the accepted forms of payment.

The next provisions of the CRD (Articles 9-14) determine in detail the right of the consumer to withdraw from a distance contract or off-premises contract over a period of 14 days without giving any reason and without incurring any costs other than those precisely provided for in those regulations; they stipulate consequences of omission of information on the right of withdrawal - in such a case the withdrawal period expires 12 months from the end of the initial withdrawal period. The consumer exercises his right of withdrawal from the contract by informing the trader of his decision before the expiry of the withdrawal period. For this purpose, the consumer may use the model withdrawal form as set out in an annex to the CRD, or he may make any other unequivocal statement setting out his decision to withdraw from the contract. The effects of withdrawal from the contract, the obligations of the trader and the obligations of the consumer in the event of withdrawal have been detailed in the CRD, too.

Significant provisions have been made in order to eliminate hidden costs, by way of which consumers gain protection against any type of price traps. The directive provides for the obligation to reveal the total cost of goods or services; if the trader fails to meet the information requirements concerning extra charges or costs, the consumer shall not be bound to cover 
these expenses, and if the trader has not obtained the consumer's express consent but has inferred it by using default options which the consumer is required to reject in order to avoid the additional payment, the consumer shall be entitled to reimbursement of this payment (Art. 22). The aim is to eliminate extra payments for the use of credit cards and telephone lines used by the consumer to get in touch with the trader with regard to the contract (pursuant to Art. 19, Member States shall prohibit traders from charging consumers, in respect of the use of a given means of payment, fees that exceed the cost borne by the trader for the use of such means).

\subsection{Assessment}

The purpose of the Consumer Rights Directive was not only to extend the protection of consumers but also to abolish legal differences (by adopting the maximum harmonisation rule), found to be a fundamental barrier to the development of cross-border trade, including online transactions. In view of the fact that the chief reason for a consumer to refrain from online shopping abroad is a lack of trust and the uncertainty as to the legal regulations binding in such a situation and as to the actual possibility of enforcing one's rights, it seems that the mere fact of harmonising rules and increasing the transparency of deals by way of a standardised scope of information addressed to the consumer should undoubtedly contribute to overcoming those barriers.

The benefits for consumers, related above all to broader access to information that will facilitate making conscious decisions when buying online, translate ultimately to benefits of the traders: increasing trust in the electronic forms of shopping will serve to promote them, and the awareness of uniform rights on the EU market allows for overcoming fears and psychological opposition against concluding cross-border contracts.

The opportunity to withdraw easily, and at no cost, from a failed transaction within 14 days reduces risks and raises the sense of safety of the consumer, thus increasing the probability of purchases on the Internet by those yet undecided or sceptical about online shopping. On the other hand, one must take into account a potential rise in the number of returns and, consequently, the growth of operating costs of businesses.
One-off costs incurred by traders when adjusting the software of websites and the rules of shops, as well as when traders have to implement new template contracts taking into account the content of new regulations, should be set off in the long term by savings on costs of legal service thanks to the standardisation of rules of business in the cross-border trade on the EU market, as well as by a drop in transaction costs in view of the standardisation of promotion in cross-border trade. Positive to both consumers and traders, the consequences of the CRD will ultimately serve to eliminate the barriers that hinder electronic cross-border commerce and to bolster the chances of small and medium companies.

\section{Digital Single Market}

Further harmonisation of the law on electronic commerce within the EU will be related to the implementation of legislative initiatives under the so-called Digital Single Market Strategy for Europe. In spite of the dynamic increase in the number of e-commerce transactions concluded in the EU, a vast majority of them are domestic transactions executed in particular countries. In 2014 , only $16 \%$ of all online transactions in the EU were also cross-border deals (Proposal for a Regulation on cross-border parcel delivery services, 2016). This means that the potential benefit from access to foreign markets via the Internet is used only fractionally. This state of affairs could change as a result of the implementation of the Digital Single Market Strategy proclaimed by the European Commission on 6 May 2015 (Communication from the Commission, 2015).

In May 2016, the European Commission presented three initiatives striving towards the elimination of the chief barriers to development of electronic commerce within the single market. The goal of those initiatives is:

a) to prevent geo-blocking and other forms of discrimination based on customers' nationality or place of residence,

b) to reduce postal charges for cross-border parcels, and

c) to improve the protection of consumers and to establish guidelines as to unfair commercial practices in the digital world. 


\subsection{Preventing Geo-Blocking}

Citizens of the EU may freely purchase goods in other countries. However, this concerns chiefly purchases made in brick-and-mortar shops when the customer stays temporarily in a different state. Such shopping concerns mostly towns close to the border and tourists. As shown by research of the European Commission, in the case of online shopping in other states, it often happens that access to a website is blocked and the Internet user is rerouted to a website in the home country of the Internet user or payment by credit or debit card from a particular country is required (so-called geo-blocking). Blocking such transactions means that it is impossible to use the potential of benefits yielded by the Internet. Such a state of affairs is incompatible with the overall objective of the EU of building a single market.

In view of the above, the European Commission has presented a proposal for a regulation on addressing geo-blocking and other forms of discrimination based on customers' place of residence or place of establishment or nationality, which is to ensure equal treatment of Internet users doing shopping on websites in other EU member states. The regulation provides that Internet users should have access to the same language versions of websites of a seller from a different country, the same product range, terms of trade and forms of payment, irrespective of their nationality and place of residence (Articles 3-5). Discriminatory treatment of Internet users from other countries shall be admissible only if it is objectively justified for reasons of taxation or of public interest (Proposal for a Regulation on addressing geo-blocking and other forms of discrimination based on customers' nationality, 2016). At the same time, the regulation stipulates that all restrictions imposed on traders with regard to passive sales shall be void (Art. 6). In order to ensure the enforcement of the said rules in each EU member state, the member states shall designate a body responsible for the enforcement of the aforementioned rules, and in relation to this, each member state shall appoint a body for providing practical assistance to Internet users in case of a dispute with traders (Articles 7-8).

\subsection{Cross-Border Parcel Delivery Services}

One of the important barriers to the development of cross-border trade within the EU are high costs of international parcel deliveries. The price advantage of traders from, for instance, Poland over a competitor from West Europe may be offset by high costs of delivery the consumer would have to bear if deciding to have a good delivered from Poland. From a study of the European Commission it follows that "[...] the prices charged by universal service providers for cross border deliveries are often three to five times the domestic price" (Proposal for a Regulation on cross-border parcel delivery services, 2016). The European Commission names several reasons for this state of affairs, among them: (i) high barriers to market entry of international deliveries, (ii) ineffective and inconsistent regulatory oversight over international delivery services, which leads to member states lacking information necessary to identify possible market failures, (iii) the poor knowledge of consumers and firms on operators and prices, as well as (iv) the price policy of retailers (Proposal for a Regulation on cross-border parcel delivery services, 2016).

The European Parliament and Council proposal for a regulation on cross-border parcel delivery services is an attempt to change this situation. The proposal is supposed to improve the effectiveness and consistence of regulatory oversight in the postal sector, stimulate competition, and reduce prices and unjustified price discrepancies by raising price transparency. The new regulation is to warrant domestic regulatory bodies' access to data needed by them to monitor cross-border markets and to verify the price availability, as well as to set prices depending on the costs (regulatory oversight). As part of that oversight, postal operators delivering parcels will pass on, to the national regulatory body, information on the turnover generated by the operator with parcel delivery services made in the country, and with cross-border postal deliveries arriving to and leaving the country (Art. 3). At the same time, operators rendering universal services will provide the domestic regulatory bodies with public price lists of charges for the delivery of postal parcels. Next, the European Commission will publish these on a website in order to increase competition and improve 
the transparency of tariffs. As part of the regulatory oversight, domestic regulatory bodies will also evaluate the affordability of charges for cross-border services of parcel delivery, juxtaposing them among others with charges for comparable domestic parcel delivery services in the member state of consignment and the member state of final destination, including charges for postal deliveries coming from other member states. They will also check if the charges in question have been applied uniformly to parcels going to at least two member states. If the domestic regulatory body determines that the charges for the cross-border deliveries were not affordable, then the operator will have to present information justifying the level of the charges. The regulation is also supposed to introduce the rule of transparent and non-discriminatory cross-border access of third parties to cross-border services or the infrastructure of parcel delivery (Art. 6).

\subsection{Cooperation of Consumer Protection Bodies}

At the moment, the cooperation between EU member states in terms of consumer protection is subject to Regulation (EC) 2006/2004 of the European Parliament and of the Council of 27 October 2004 on cooperation between national authorities responsible for the enforcement of consumer protection laws. The forms of cooperation stipulated under this regulation were created bearing in mind the needs of traditional economy and they do not ensure a fast reaction to European Union-wide practices violating consumer rights on the Internet.

In line with the Proposal of amendments to Regulation 2006/2004, national consumer protection authorities will be able to, among others, obtain data identifying sellers guilty of violating consumer rights from online service suppliers, owners of domain registries and banks (Art. 8.2b), to use the mystery shopper institution in order to verify the occurrence of violations (Art. 8.2f), such as for instance geo-blocking, and to order the shut-down of a website or a domain (Art. 8.21).

The regulation determines also that in the case of violations of consumer rights extending to more than one member state, the European Commission will ensure that only one coordinated, one-stop-shop review be run. This will enable a faster reaction and will limit the costs of holding multiple procedures within the EU.

\subsection{Fighting Unfair Commercial Practices}

Adopting Directive 2005/29/EC of the European Parliament and of the Council of 11 May 2005 concerning unfair business-to-consumer commercial practices constituted an important step towards harmonising the interests of consumers in the EU. The momentousness of the directive results from the fact that it is based on a definition of unfair commercial practices which in itself has to be regarded as success, considering the diversity of legal cultures within the EU in their approach to such terms as honesty and professional diligence. The directive is comprehensive, because it covers, as a whole, commercial contacts between business and consumers, i.e. contacts from before concluding a transaction (promotion, marketing), during and after the transaction. At the same time, the directive has been devised to be flexible - general clauses describing various categories of unfair market practices have been supplemented by a hands-on list of practices considered unfair in all circumstances. Domestic provisions adopted on the basis of the directive are frequently applied by domestic authorities for consumer protection. Concurrently, nearly $48 \%$ of all cases handled by the European Consumer Centres from 2007 until 2015 concerned the scope of the directive (European Commission, 2016).

The goal of the updated guidance of the European Commission is to clarify which measures of traders in the digital world qualify as unfair commercial practices. Amongst the numerous detailed recommendations, the new guidance describes situations in which online platforms shall be considered traders ${ }^{10}$. These platforms act, as a rule, as an agent between business and consumers; however, they will qualify as traders subject to information requirements pursuant to the directive, e.g. if they charge a commission fee for a deal concluded through a website (Commission Staff Working Document Guidance on the implementation/application of Directive 2005/29/EC on unfair commercial practices). Moreover, the owners of online platforms should clearly state that the legal protection of consumer applies only to the transaction with users of platforms which 
are also traders. At the same time, online platforms should be organised in such a way as to enable the traders using them to meet the information duties imposed on traders. With regard to search engines, the Guidance demands among others the unambiguous separation of results of the so-called natural search from sponsored search hits. The Guidance also determines the requirements of presenting commercial offers via price comparison websites.

\section{Conclusions}

From the point of view of practice of electronic trade, the standardisation on an international scale of all legal rules pertaining to commercial law seems to be an optimal solution. Over recent years, the unification of the legal framework for electronic commerce in the EU has become increasingly prominent. The harmonisation of law serves the implementation of one overriding goal, i.e. the establishment of a single market also with regard to services provided online. The harmonising initiatives reach widely, as they are among others to stimulate competition on the Internet, to limit transaction costs and to protect consumer interests. It can be thus expected that they will eventually result in an increase of security of online trade and a rise of the share of cross-border transactions in the overall number of online transactions carried out within the EU.

On account of the nature of the Internet, harmonisation of the legal framework for electronic commerce, restricted to the single market of the EU, seems insufficient. In the meantime, progress in harmonising the legal framework for electronic commerce on a wider, international (global) scale seems very limited, against the backdrop of harmonisation in the EU. Although there is already a certain standardisation acquis with regard to both business-to-business (B2B) trade and consumer trade (B2C), over the past years there has been hardly any progress regarding the ratification of the fundamental convention that constitutes the legislative model of essential online transaction terms, i.e. the Convention on the Use of Electronic Communications in International Contracts. In view of the above concerns, differences in regulating e-commerce around the world create barriers to the development of using the Internet for cross-border trade.

\section{Endnotes}

1 For economic entities operating in international trade, this means the necessity of not only keeping track of regulations under alien legal systems, but also of knowing the rules on conflict of laws. Furthermore, applying flexible linking factors (such as the 'closest connection' principle in law), in addition to exact linking factors, such as the place of business, place of registration, place of conclusion or performance of contract, increases the margin of freedom the judge has when determining the applicable law with respect to a contract, which also restricts the predictability of rulings.

2 We treat among others the regulations of the UN Commission on International Trade Law on electronic commerce and electronic signatures (UNCITRAL Model Law on Electronic Commerce (1996); UNCITRAL Model Law on Electronic Signatures (2001)) as model laws.

3 Many conventions have never come into force due to insufficient ratifications needed for the act to come into effect or they have never taken on practical meaning in view of the tiny number of states that acceded the conventions. The UN Convention on Contracts for the International Sale of Goods, drafted in Vienna on 11 April 1980 and ratified by 85 states (status as of 3.5.2016 http:/www.uncitral.org/uncitral/ en/uncitral_texts/sale_goods/1980CISG_status. html) is a positive exception to the rule. Poland has been party to the said Convention since 1.6.1996 (Journal of Laws of 13 May 1997).

4 The definition of an international (sales) contract according to the Vienna Convention: the sale of a good is considered international if the parties to the contract have their places of business in different states.

5 Pursuant to Article 1.1 of the Vienna Convention, it shall apply to contracts of sale of goods between parties whose places of business are in different states: (a) when the states are Contracting States; or (b) when the rules of private international law indicate the application of the law of a Contracting State.

6 The Vienna Convention devotes particular attention to concluding contracts between those absent, i.e. by exchanging an offer and an acceptance. In this area differences between national laws with regard to the terms of validity of an offer and of accepting it, determining the moment the parties entered into the contract etc., were particularly cumbersome for international trade practice.

7 Ratification status as of 1.7.2016, http://www. uncitral.org/uncitral/en/uncitral texts/electronic_commerce/2005Convention_status.html.

8 Predictions made about the extension of the group of States Parties to the Convention have not come true; indeed, in spite of signing the 
Convention on 06.07.2006, China has still not ratified the act (as of 25.08.2016).

9 For the overview of the EU initiatives in this area refer to: http://ec.europa.eu/justice/contract/digital-contract-rules/index_en.htm.

10 For instance, search engines (e.g. Google, Yahoo!), social networking sites (e.g. Facebook, Twitter), review-collecting websites (e.g. Tripadvisor), price comparison websites (e.g. Trivago. com, Rentalcars.com, Kayak.com, Booking. com), collaborative economy platforms (e.g. Airbnb, Uber, BlaBlaCar), e-commerce platforms (marketplaces, e.g. Zalando, Alibaba, Ebay), app stores (e.g. Apple App Store, Google Play), collective buying websites (e.g. Groupon)

\section{References}

European Commission. (2016). Protecting consum ers against misleading and aggressive commercial practices, Fact sheet, May. Retrieved from: http:// ec.europa.eu/consumers/consumer_rights/unfairtrade/docs/upc-factsheet_en.pdf.

Mokrysz-Olszyńska A. (2013). Dyrektywa 2011/83 UE z dnia 25 października 2011 w sprawie praw konsumentów jako kolejny etap na drodze tworzenia jednolitych reguł konkurencji na unijnym rynku [Directive 2011/83/EU of 25 October 2011 on consumer rights as the next stage towards creating uniform competition rules for the EU market]. Internetowy Kwartalnik Antymonopolowy i Regulacyjny, (7)

Polska Izba Informatyki i Telekomunikacji (PIIT) [Polish ICT Chamber]. (2016). Opinia Polskiej Izby Informatyki $i$ Telekomunikacji [PIIT] $w$ sprawie podpisania $i$ ratyfikowania przez Polskę Konwencji UNCITRAL o wykorzystaniu komunikacji elektronicznej w kontraktach międzynarodowych [Opinion of PIIT (Polish ICT Chamber) on Poland signing and ratifying the UNCITRAL Convention on the Use of Electronic Communications in International Contracts] (PDF). Retrieved from: www.piit.org.pl/ documents/10181/31329/5087.pdf.

Waglowski, P. (2006). Czy mamy wejść w konwencje ONZ o handlu elektronicznym? [Should we accede the UN convention electronic commerce?], 29 August. Retrieved from: http://prawo.vagla.pl/ node/6598.

\section{Sources of law}

Communication from the Commission to the European Parliament, the Council, the European Economic and Social Committee and the Committee of the Regions, A Digital Single Market Strategy For Europe, Brussels, 6.5.2015, COM(2015) 192 final.

Commission Staff Working Document Guidance on the implementation/application of Directive 2005/29/EC on unfair commercial practices, Brussels, 25.5.2016, SWD(2016) 163 final.
Directive 2005/29/WE of the European Parliament and of the Council of 11 May 2005 concerning unfair business-to-consumer commercial practices in the internal market and amending Council Directive 84/450/EEC, Directives 97/7/EC, 98/27/EC and 2002/65/EC of the European Parliament and of the Council and Regulation (EC) No. 2006/2004 of the European Parliament and of the Council, Official Journal of the European Union (OJ L 149/22, 11.6.2005).

Directive 2011/83/EU of the European Parliament and of the Council of 25 October 2011 on consumer rights, amending Council Directive 93/13/EEC on unfair terms in consumer contracts and Directive 1999/44/EC on certain aspects of the sale of consumer goods and associated guarantees and repealing Council Directive $85 / 577 /$ EEC to protect the consumer in respect of contracts negotiated away from business premises and Directive 97/7/EC on the protection of consumers in respect of distance contracts (OJ L 304/64, 22.11.2011).

Proposal for a Regulation of the European Parliament and of the Council on addressing geoblocking and other forms of discrimination based on customers' nationality, place of residence or place of establishment within the internal market and amending Regulation (EC) No. 2006/2004 and Directive 2009/22/EC, Brussels, 25.5.2016, COM(2016) 289 final, 2016/0152 (COD).

Proposal for a Regulation of the European Parliament and of the Council on cooperation between national authorities responsible for the enforcement of consumer protection laws, Brussels, 25.5.2016, COM(2016) 283 final, 2016/0148 (COD).

Proposal for a Regulation of the European Parliament and of the Council on cross-border parcel delivery services, COM/2016/0285 final - 2016/0149 (COD).

Regulation (EC) No. 2006/2004 of the European Parliament and of the Council of 27 October 2004 on cooperation between national authorities responsible for the enforcement of consumer protection laws (OJ L 364, 9.12.2004).

UNCITRAL Model Law on Electronic Commerce (1996).

UNCITRAL Model Law on Electronic Signatures (2001).

United Nations Convention on the Use of Electronic Communications in International Contracts of 23 November 2005.

United Nations Convention on Contracts for the International Sale of Goods, drafted in Vienna 11 April 1980 [Polish version: Journal of Laws of 13 May 1997].

Ustawa z dnia 30 maja 2014 r. o prawach konsumenta [Act of 30 May 2014 on consumer rights] Journal of Laws of 2014, item 827. 